\title{
Dora Maček: Nijanse modrog u pjesmama Susanne Jorn
}

Pjesništvo Susanne Jorn intimno je s mnogo kratkih pjesama koje često izražavaju osjećaje, atmosferu i dojmove. Tu su osobna viđenja prirode i ljudi, doživljena, mogli bismo reći, na slikarski način. Boje su gotovo redoviti sastavni dio tih doživljaja i kao na slikama, stvaraju dramatičnu ili smirenu atmosferu. One su izraz prirode koja okružuje pjesnikinju, ali su i izraz osjećaja i duševnih stanja. To se jasno pokazuje u zbirci Ne sada već sad, čiji je okvir paleta plavih boja. Druga scena njezine poezije sličice su iz japanskog života i japanske umjetnosti i pjesništva, koje mnogo puta prenosi u svoju dansku okolinu. U zbirci Ne sada već sad mnoge su pjesme prizori iz Danske ili Tokija, ali i drugih krajeva svijeta gdje je boravila. Ipak, njezino je pjesništvo prije svega vezano uz nordijsko nebo, zemlju i kulturu te sjećanja na oca (poznatog danskog likovnog umjetnika Asgera Jorna, koji je u svojim djelima spajao različite vrste umjetnosti. Asger Jorn bio je član poznate transnacionalne udruge CoBrA, koja je djelovala početkom 1950-ih godina). U mnoge se pjesme određenih osjećaja i ozračja skladno uklapaju i japanski i danski krajolici te japanski i, ako tako možemo reći, nordijski pjesnički izraz. Unatoč vrlo intimnoj poeziji, kao i većina skandinavskih pjesnika i pjesnikinja, Susanne Jorn osjetljiva je na sudbu današnjeg čovjeka bilo gdje u svijetu i ona nalazi značajno mjesto u njezinu pjesništvu.

Kao ilustracija ovom kratkom prikazu poslužit će izbor pjesama iz zbirke Ne sada već sad (Ikke nu men nu). Izbor uključuje samo (ili gotovo samo) tip pjesama koje su izrazito „slikarske“ po pitanju motiva i odabira riječi. Prijevodi nisu konačni, već su to prijevodi „u radu“ i otvoreni potencijalnim prijedlozima čitatelja. Prevoditelju često treba dijalog s nekim tko ima drugačije asocijacije i drugačija iskustva s jezikom. Moj je pristup daleko od literarno-znanstvenog ili kritičkog, on je više spontana fascinacija riječima, što je slično učinku kakav riječi i glasovi imaju na pjesnika, kao što na jednome mjestu kaže i Susanne Jorn. Ne mogu za sebe reći ni da se bavim teorijom prevođenja, nego prevođenje više shvaćam kao izazov - kako najbolje prenijeti pjesmu na 
hrvatski. To je neka vrsta rješavanja problema i jedan od ljepših načina na koji se mogu spojiti duhovna aktivnost i relaksacija. Neke od dilema na koje sam naišla u prijevodu donosim u nastavku ovog kratkog uvoda.

Samo ime zbirke je neobično, a doslovce znači, kako sam i ja u prvi mah prevela, Ne sada ali sada. Tu se odmah vidi prva prepreka, gotovo mehanička, koju hrvatski jezik postavlja prevoditelju jer skandinavski jezici imaju mnogo više kratkih riječi nego hrvatski, djelomično i zato što su kroz povijest izgubili većinu padežnih oblika, pa time i slog viška koji se u hrvatskom teško može izbjeći. U ovom slučaju, gdje nije riječ o morfološkim oblicima, postoje i kraći, jednosložni oblici, za koje sam se u drugom i trećem promišljanju odlučila. Tako mi se čini da je prijevod Ne sada već sad bolji jer je sveden na sličan ritam ili barem na isti broj slogova kao u danskom originalu.

Zbirka ima devet podnaslova, koji daju opće ozračje cijeloj zbirci, jer su čitava paleta plavih boja, primjerice, modra poput vode, poput neba, safirno modra i sl. Pa premda sve izgleda jednostavno, u danskom je pjesnikinja sve te boje izrazila složenicama, tj. vandblat, himmelblat, safirblat, što je trn u tekstu koji se redovito javlja, pogotovo u prijevodima s germanskih jezika. Takav se sažet izraz teško prevodi, a u stihu je gubitak ritma gotovo neizbježan. No još je manje jednostavno kad se u hrvatskom ne nađe uvijek dobar pridjev kao safirno ili nebeski, nego eventualno takav pridjev navodi na pogrešnu asocijaciju kao vodeno modro ili je po obliku nezgodan kao očno modro. Tu sad, čini se, nema druge nego koristiti usporedbu s veznikom kao/poput i reći modro kao oči/poput očiju. Ovdje možemo dalje odlučivati o duljem ili kraćem te manje ili više „poetičnom“ obliku. Mala dilema postoji i u slučaju tokijskog modrila, tj. u naslovu Tokyoblat - hoću li reći tokijski modro ili tokijsko modro? Dakako, i sama riječ modro mogla bi biti plavo, što bi etimološki bilo bliže danskom blat, a i plavetnilo bi u ovom kontekstu bila bolja imenica tamo gdje se traži, nego modrilo . No osim takvih mušica hrvatskog pjesničkog izraza, postoje i one gdje je više poezije u riječima poput i modro nego u riječima kao i plavo, možda samo zato da (se) napakosti prevoditelju. U suvremenom danskom, i ne samo danskom pjesništvu, jedna je od bitnih odlika igra riječima ili glasovima, što, dakako, ne vodi uvijek uzvišenom izrazu koji se u nas često pripisuje pjesništvu, ali ju je zato teže prevesti. Ili se to samo meni čini?

U sljedećem izboru pjesama i njihovih prijevoda na hrvatski želim pokazati neke od spomenutih 
osobina poezije Susanne Jorn i komentirati mjesta na kojima sam se dvoumila ili se još dvoumim oko prijevoda.

Prva je Autobiografska pjesma iz niza naslovljenog Kričavo modro sad koja mnogo ljepše govori o pjesnikinji nego moj šturi uvodni tekst. Jedna primjedba o prijevodu koji, naravno, na početku većine strofa odstupa od originala u kojem se redovito javlja zamjenica ,jeg“, odnosno „ja“. Prevoditelji s jezika u kojima je obvezno izraziti subjekt često se povode za tim, pa ga i bez potrebe prevode u hrvatski. Takav je jezik i danski, koji zahtijeva da se subjekt izrazi. To u ovoj pjesmi dovodi do jednakih početaka u svakoj strofi, no unatoč tomu, čini mi se da bi u hrvatskom bilo suvišno. Prvi bi stih, doduše, bio vrlo sličan danskom, no drugi bi stoga bio mnogo duži. Bez „ja“ u prvom stihu ritam je bolje raspoređen. Ima, međutim, nekoliko stihova gdje je „ja“ bilo potrebno izraziti jer izražava nešto posebno kao Ja sam vidovita i Ja sam san umjesto Vidovita sam i San sam. Osim toga „san sam“ zvuči dosta nezgrapno poradi suviše sličnih slogova i ponavljanja glasa /s/. I treće, glagol „biti“, tj. „sam“, uvijek dolazi u prvi red, a ovdje bih ga morala staviti samoga u drugi ili sasvim izostaviti jedan stih. Tu bi se poremetila struktura originala.

\section{Autobiografska pjesma}

\section{Rođena sam}

u Kopenhagenu 1944.

U kolovozu 1945. mi je prezime

Jorgensen promijenjeno u Jorn.

\section{Zvala sam se}

SUS odnaprijed i odostrag,

moj prvi palindrom.

Voljela sam

slova, riječi, njihov zvuk

i zvukom sam se igrala. 


\section{Rasla sam}

na Norrebro u domu

s klavirom i metronomom.

Kad bi došli gosti, pjevala sam im

ili svirala klavir.

Imala sam pletenice

i nosila suknje sa škotskim karom.

Crveno mi je bila omiljena boja -

Došla sam u

vrtić u ulici Hjorto na Osterbro, kad su mi bile

dvije.

Zidove u vrtiću oslikali su slikari COBRA-e

Prvih sam jutara

vrištala od straha,

kad bih ugledala plakat

s lavom iz zoološkog vrta, koji riče,

pa sanjala i sanjala više godina o razjapljenim

raljama.

Ukrala sam

jedan od susjedovih bijelih tricikala,

koji je stajao pod kuhinjskim stubama.

$\mathrm{Ne}$, ne, posudila sam bijeli tricikl,

jer nije bilo novca da mi se takav kupi, 
izvezla se na Tagensvej u promet

a na policiju je po mene došao otac;

ukorili su ga što bolje ne pazi na mene.

Rano sam

zavoljela putovanja.

U Illiers l’Evéque u Normandiji

bilo je večeri, kad su moja braća spavala -

tih večeri, vani je bilo svijetlo

pa nisam mogla spavati.

Na tapeti je bio uzorak,

ali i uzorak na zidu

od žohara koji su tu šuškali,

koji me je držao budnom dok se spuštao mrak

a šuškanje se nastavljalo -

U Homt Souk u Džerbi sam se

igrala sa susjedovim Salahom, Alijem i Habibom.

Prije spavanja sastajali smo se na putu

da gledamo mjesec na arapskom nebu.

Otputovali smo prije dolaska kameleona u travnju

1948.

Bilo mi je

18 kad je baka ispričala

da smo je posjetili u Silkeborgu 
na povratku iz Džerbe 1948.

Baka je ispričala

da sam tada izišla u njenu kuhinju,

uzeti nešto za jelo, ali sam morala pričekati

do idućeg obroka.

Baka je ispričala

da u Džerbi sigurno nismo imali dovoljno za jelo,

jer sam pitala:

- Imaš li što za jesti?

Imam

na desnom koljenu ožiljak iz ljeta 1949.

kad je na Bronholmu razvrgnut brak mojih

roditelja.

Mnogo nas se kupalo na kamenoj obali - ali

ja sam se poskliznula na kamen na dnu, pala i

udarila u nešto oštro.

Nisam vidjela

svog oca, baku, tete, stričeve, sestrične i bratiće 13

godina.

Zaljubila sam se

najprije u Jorgena -

Prolazila sam

svoju prvu katarzu, 
kad sam navršila dvoznamenkasti broj - 10 godina.

A iduću, svako desetljeće.

Putovala sam

u Pariz sama 1967.-68.

na studij kineskog, japanskog, tibetanskog

jer sam bila silno fascinirana slikovnim pismima,

no u Parizu sam uglavnom pisala pjesme.

U proljeće '68. bila je pobuna.

U oči mi je ušao suzavac

pri protestu na Boulevardu Saint-Michel.

Otišla sam

od svog zaručnika iduće godine.

Želim

Pošto poto u Japan -

Debitirala sam

1970. sa zbirkom pjesama Krhotine,

dok sam u Kyotu bila stalno naseljeni zapadnjak.

Udala sam se

za Amerikanca

u Kobeu 1971. Kasnije

smo u SAD-u dobili dva sina.

Izgubila sam

krvi, znoja, suza, 
kad je moj muž izgubio mene -

a ja njega.

Imam

od tada na srcu ožiljak.

Sletjela sam

u zračnu luku Kastrup na Uskrs 2000.

Ja sam

vidovita.

Ja sam

san,

učinjen od tvari sna.

Imam

nedužno lice,

neku velikodušnost.

Stojim

danas

ovdje na Hojbrou

usred rodnog grada

Kopenhagena.

Znam

da sam živjela i

da živim

u tom tajanstvenom plavetnilu 
ne sada, već sad.

Sljedeća kratka pjesma iz niza s naslovom Modro kao mjesec sad slijed je usklika oduševljenja nad prizorom. Započinju pokaznom zamjenicom zapravo mišljenom kao uzvik „gledaj!“. U hrvatskom se pokazna zamjenica to slaže s danskom dette u početnom konsonantu, premda bezvučnom, što je bolje nego ovaj, ova, ovo, pogotovo u funkciji uzvika, barem prema mom shvaćanju. Kratki oblik imenica vjetri i vali ritmički se bolje uklapaju u pjesmu. Posljednjih nekoliko stihova pokazuje množinu riječi koje su u hrvatskom potrebne da se prevedu složenice.

\section{Modro kao mjesec sad}

To čarobno more.

To magično nebo.

Ti divlji vjetri.

Taj pijesak.

Taj obzor.

Ti vali.

To more crno ko noć.

Taj mjesec modar ko ponoć.

Te vrtoglavo bijele mjesečeve zrake.

Evo još jedne impresionističke slike s danskog otoka Skagena, gdje različite boje zorno pokazuju gustinu danskog izraza koji se u hrvatskom prijevodu neminovno razuđuje. I povrh toga odlučila sam se za rješenje da boje gron, rod prevedem kao zelenilo, crvenilo, što je ipak donekle zgusnulo izraz i ritam. Dvije boje na danskom imaju isti samoglasnik koji nosi slog, a i u hrvatskom se ponavlja „e“ u drugom slogu riječi, pa to donekle ostvaruje osnovnu harmoniju zvuka.

\section{Skagen}

Skakavaca zrik - i 
Zelenilo mahovine

Zelenilo paprati

Zelenilo lišaja

Crvenilo vrijeska

Crvenilo šipka

Sličnog je ugođaja i sljedeća pjesma iz niza Safirno modro sad, s naslovom Visby modar kao obzor. Ugođaj je to nordijske ljetne večeri na otoku Gotlandu, gdje se nalazi grad Visby.

\section{Visby modar kao obzor}

Kada

Jako

Lipanjsko

Svjetlo

Postojano

Dolazi

I

Smješta

Se

Unutra

Onda

Se

Otvara

Astronomski

Nebeski 
Modar

Nebeski

Svod

$U$

Beskonačno plavetnilo.

Plavetnilo različka

Dani

Rastu,

Kao sumrak modre

Noći se

Skraćuju

Dok se

Čarolija

$U$

10.000

Stvari

Života

Između

Neba

I

Mora

Vidi

Tako 
Jasno

I

Tako

Oštro,

$\mathrm{Da}$

$\mathrm{Se}$

Moramo

Čuditi

Čudu

Života.

U ovoj pjesmi redak je sastavljen od jedne riječi, što sam pokušala slijediti. Na žalost, složenice su ispale višerječne, ali sam ih zadržavala u jednom retku npr. Kornblomstbla - Plavetnilo različka. S druge su strane povratne konstrukcije, npr. Undres - čuditi se, mogle ispuniti dva retka i na kraju smo završili s istim brojem stihova, premda ne uvijek s jednom riječi po stihu.

I sljedeće su dvije sličice iz istoga niza, a prikazuju dva oprečna raspoloženja koja nastaju u sjevernim krajevima: nasuprot optimizmu i ushićenju za svijetlih večeri u Visbyju, gdje pjesnikinja često ljeti boravi, kad joj se čini da nosi „Haljinu Svjetla“, tu su tmurni mračni zimski dani u gradskom okolišu Kopenhagena, gdje „sve miriše na tminu“ i mrak je vidljiv, raspoloženje tmurno, a ona uvijena u „Haljinu Tame“. Nastoji se prilagoditi, ali ne može.

U ovim stihovima ima teških složenica poput vildereblat > divljije modro, kao i nominalizacija Det Kobenhavnske, koja se tvori jednostavno s određenim članom uz pridjev dok je hrvatska imenica vrlo nespretna „kopenhaškost“. Plavo, pozitivno svijetlo suprotstavljeno je tami. Ovdje sam započela koristeći, čini mi se, poetskije riječi kao što su tama, tmina, tmurno, ali kako sam lingvist, dapače, povjesničarka jezika, nisam mogla odoljeti srodnosti danske riječi morke i njenih izvedenica, s hrvatskom riječi mrak s izvedenicama. Tako sam sve „tmine“ najzad zamijenila 
„mrakom“. Možda sam se najviše kolebala kod „tmurnog raspoloženja“ prema „mračnom“, ali mi se onda učinilo da može i tako.

\section{Hubris}

Otputuješ sasvim na sjever u Visby

upoznati se sa svjetlom u lipnju.

Spopada te

divljije modro svijetlo čuvstvo.

Odjevena u Haljinu Svjetla

vraćaš se

u kopenhaškost

a sa sobom imaš sve plavetnilo.

\section{Tu miriše na tminu}

Vidiš mrak noći,

Vidiš Neviđeno.

Ostaješ preko zime u Kopenhagenu

pa primjećuješ mrak u prosincu.

Imaš

mračnog raspoloženja nadivljije crne misli.

Odjevena si u Haljinu Mraka

ne sanjaš da nisi tu

ne misliš da nisi tu.

Ne smeta. 


\section{Smeta.}

Sljedećih nekoliko pjesama iz niza Modro kao oči sad očito su nadahnute japanskim i kineskim što slikarstvom što pjesništvom. Već i naslovi pjesama označavaju poznate tipove slika i premda prizori nisu nužno japanski, pjesnički izraz jest. Možda samo jedna prevoditeljska primjedba. U Kolažu, due je „golubica“ premda danski u načelu ne razlikuje gramatički rod. No povijesno (a i u švedskom) to je imenica ženskog roda i označavala je ženku. Stoga nije bilo dileme između „goluba“ i „golubice“, koji u hrvatskom oboje simboliziraju pticu mira. Uz to, u hrvatskom se „golubica“ slaže s „povorkom“ i „sjenom“, pa je kontrast sažet u te tri imenice.

\section{Kolaž}

Žuta mirovna povorka

Bijela golubica

Crna sjena

\section{Minijatura}

Admiral

na čičku.

\section{Mrtva priroda}

Prozor

Kuhinjski stol

Šipak

Šipkova sjena

Klementina 
u zdjeli

nedostaje

Pun mjesec

A evo i dvije haiku pjesme. Ovdje je dobro paziti na duljinu stiha (broj slogova) premda mu ne treba robovati. Ritam također nije nevažan, pa sam se stoga u drugoj pjesmi odlučila za „krila šum“ umjesto „šum krila“, kad se već ne može reproducirati danski „krilošum“ (vingesus), a da ne ispadne šaljivo.

\section{Kigo $^{11}$}

Poput knjige zeleno -

životna radost

Polja repice -

unutarnje nebo

Jedan dah vjetra

i sve postaje

žuto kao zanovijet.

\section{Danski hanam?}

Biserno bijeli oblaci

preko travanjskog neba

Šumsko tlo s anemonama

leptirovih

krila šum

Pianissimo 
[1] Japanska riječ za godišnje doba. Suvremena se japanska haiku poezija nastoji odvojiti od tradicionalnog haikua, gdje se riječ za godišnje doba morala koristiti.

[2] Na japanskom gledati cvijeće, kao što Japanci gledaju trešnjin cvat

\section{(c) (i) $\Theta($}

Creative Commons Attribution-NonCommercial-NoDerivatives 4.0 International License 